\title{
Enumeration, Resuscitation, and Infectivity of the Sublethally Injured Erwinia Cells Induced by Mild Acid Treatment
}

\author{
Ching-Hsing Liao and Lisa M. Shollenberger
}

U.S. Department of Agriculture-Agricultural Research Service, Eastern Regional Research Center, 600 East Mermaid Lane, Wyndmoor, PA 19038.

Accepted for publication 9 September 2003.

\begin{abstract}
Liao, C.-H., and Shollengerger, L. M. 2004. Enumeration, resuscitation, and infectivity of the sublethally injured Erwinia cells induced by mild acid treatment. Phytopathology 94:76-81.

Current knowledge about microbial injury was derived mostly from studies with bacteria associated with processed foods. Demonstration of injury and repair in phytopathogenic bacteria and its implication on pathogen detection and disease ecology have not been reported. The objective of this study was to investigate the lethal and sublethal effects of acetic acid (AA) on soft-rot Erwinia spp. and the limitation of using selective media for isolation of injured cells. Following exposure to $0.3 \%$ AA for $6 \mathrm{~min}, 90$ to $99 \%$ of E. carotovora subsp. carotovora, E. carotovora subsp. atroseptica, and E. chrysanthemi cells were killed. When AA-treated samples were plated on agar media, the number of

agar was $3 \log$ units higher than that recovered on selective media such as crystal violet pectate (CVP). Lethal and sublethal actions of AA on Erwinia spp. were affected greatly by acid concentration, exposure time, and bacterial strains tested. Injured Erwinia cells were able to repair and regain the ability to grow on CVP when placed in nutrient broth but not in selective broth containing crystal violet and sodium dodecyl sulfate. Injured cells also were able to resuscitate on cut surfaces of cucumber fruit and to induce soft rot on green bell pepper. Together, these results suggest that direct use of selective media for isolation of Erwinia spp. could limit the recovery of injured cells in samples that have been exposed to chemical or physical stresses. Enrichment of these samples in nutrient broth before plating on CVP is expected to improve the detection of injured Erwinia spp.
\end{abstract} bacteria recovered on nonselective media such as brain heart infusion

The widespread use of selective media for isolation of bacteria began in approximately 1920, but the limitation of using these media for detection of foodborne pathogens was not realized until quantitative studies revealed the poor recovery of viable bacteria following heating, drying, or freezing (1). It now is generally believed that, following exposure to a variety of physical or chemical stresses, bacteria can be killed, injured, or unaffected (27). Hartseli (13) was among the first to define "injured bacteria" as those capable of forming colonies on nonselective but not on selective media. Previous studies of microbial injury were focused almost exclusively on bacteria that were associated with food or drinking water (7). Demonstration of injury and repair in phytopathogenic bacteria, including soft-rot Erwinia spp., has not yet been reported.

As pre- and postharvest pathogens, soft-rot Erwinia spp. frequently are found in soil, irrigation water, and plant debris (19, 24). Several selective media, including crystal violet petate (CVP) (8), D3 (14), and pectate Tergitol (PT) (6), have been developed for isolation of soft-rot Erwinia spp. from plant and environmental samples. Plating efficiencies of these media for recovery of Erwinia spp. were evaluated, usually using bacteria propagated in the laboratory. Limitation of these media for isolation of injured Erwinia cells from the environment or sanitized produce samples has not been considered or investigated. Meneley and Stanghellini (21) reported that isolation of Erwinia spp. from soil could be improved by incubating the samples in a semiselective broth

Corresponding author: C.-H. Liao; E-mail address: cliao@errc.ars.usda.gov

Publication no. P-2003-1024-03R

This article is in the public domain and not copyrightable. It may be freely reprinted with customary crediting of the source. The American Phytopathological Society, 2004
Additional keywords: bacterial injury.

before plating on CVP medium. However, it was not determined if this semiselective broth enhanced the recovery of potentially injured Erwinia cells in the samples.

Several sanitizers, including chlorine (2), chlorine dioxide (31), and hydrogen peroxide (28), have been tested for their efficacies in eliminating harmful microorganisms from fresh produce. None of these sanitizers, however, is sufficiently effective to completely remove microorganisms from fruits and vegetables (3). Nevertheless, an increasing number of reports have shown that washing fresh produce and sprouting seed with acetic acid (AA) was effective for suppressing fungal decay $(10,29)$, Escherichia coli O157:H7 (32,33), Salmonella typhimurium (11), and Yersinia enterocolitica (15) on fresh produce or meat products. AA is generally recognized as safe (GRAS) and has been approved by the United States Food and Drug Administration for use as a food additive or as a disinfectant for animal carcasses (12). Although antimicrobial activities of AA against E. coli K-12 (26) and $S$. bareilly (5) have been demonstrated, its effect on phytopathogenic bacteria has not been examined. The objectives of this study were to (i) investigate the lethal and sublethal actions of AA on Erwinia spp. as affected by acid concentration, exposure time, and bacterial strains; (ii) examine the condition and time frame required for recovery of injured cells in broth media and on cut surfaces of fruit; and (iii) determine the soft-rotting ability of acidinjured Erwinia cells on bell pepper fruit.

\section{MATERIALS AND METHODS}

Bacterial strains and culture media. Five Erwinia strains, including two strains (SR319 and 1) of E. carotovora subsp. carotovora, two strains (EC16 and 120A) of E. chrysanthemi, and one strain (SR8) of E. carotovora subsp. atroseptica, were used. E. carotovora subsp. carotovora strain 1 was isolated from prepeeled baby carrot (unpublished data). E. carotovora subsp. 
carotovora strain SR319, E. carotovora subsp. atroseptica strain SR8, and E. chrysanthemi strain 120A were obtained from A. Kelman (North Carolina State University) and E. chrysanthemi strain EC16 from A. Chatterjee (Kansas State University). They were grown routinely on brain heart infusion agar (BHIA; BD Systems/Difco, Sparks, MD) at $28^{\circ} \mathrm{C}$ and maintained on the same medium at $4^{\circ} \mathrm{C}$. For enumeration of injured cells, acid-treated samples were plated on BHIA and on four selective agar media, including CVP (8), PT (6), D3 (14), and violet-red bile agar (VRBA) (BD Systems/Difco). These media were prepared as previously described $(6,8,14)$ with slight modification. In modified CVP, the medium was supplemented with sodium dodecyl sulfate (SDS) and yeast extract to a concentration of $0.1 \mathrm{mg} / \mathrm{ml}$ and $0.2 \%$ (wt/vol), respectively. In addition, the concentration of crystal violet in modified CVP was reduced to $1.0 \mu \mathrm{g} / \mathrm{ml}$. For 1 liter of modified PT medium, Tergitol7 was replaced with $0.6 \mathrm{ml}$ of XLT4 supplement (BD Systems/Difco) containing 27\% of Tergitol4. In modified D3, the concentration of $\mathrm{LiCl}$ was reduced to $0.7 \mathrm{~g} /$ liter. Polypectate for CVP was purchased from M. Burger, Inc. (Madison, WI).

Preparation of bacterial suspensions and acid treatment. Unless otherwise indicated, bacterial suspensions were prepared from cultures grown on BHIA at $28^{\circ} \mathrm{C}$ for $24 \mathrm{~h}$. Cell masses were collected from culture plates using a sterile loop and subsequently dispersed in $75 \mu \mathrm{M}$ of phosphate-buffered saline (PBS, $\mathrm{pH} 7.1$; Invitrogen Corp., Carlsbad, CA) to make a suspension with an optical density of $1.00 \pm 0.03$ at $600 \mathrm{~nm}$, which was equivalent to a cell density of 1.2 to $1.7 \times 10^{9} \mathrm{CFU} / \mathrm{ml}$. The optical density was measured using a spectrophotometer (Beckman Instruments, Fullerton, CA). A microfuge tube containing $1 \mathrm{ml}$ of cell suspension was spun at $12,000 \mathrm{rpm}$ for $1 \mathrm{~min}$ by a refrigerated microcentrifuge (Brinkmann Instruments, Westbury, NY). After centrifugation, the supernatant was discarded and the cell pellet was suspended in an AA solution prepared from glacial AA (Mallinckrodt Baker, Inc., Paris, KY) and allowed to incubate at $20^{\circ} \mathrm{C}$ for 0 to 6 min. AA-treated cells then were collected by centrifugation (12,000 $\mathrm{rpm}$ for $1 \mathrm{~min}$ ) and resuspended in $1 \mathrm{ml}$ of PBS after washing twice in the same buffer. Total exposure time of bacteria to AA included the actual incubation time plus $2 \mathrm{~min}$ required for removal of AA following the incubation. Processed samples were plated on nonselective BHIA and also on selective CVP, PT, D3, or VRBA media by spreading. Culture plates then were incubated at $28^{\circ} \mathrm{C}$ for $48 \mathrm{~h}$. The killing rate was calculated based on the difference in bacterial counts of AA-treated and water-treated samples as determined on BHIA. The injury rate was calculated based on the difference in bacterial count of AA-treated sample determined on selective agars and on bacterial count determined on BHIA. The plating efficiency of each selective medium was calculated from the difference in plate counts of water-treated samples determined on BHIA and on selective agar. Following exposure to $0.3 \%$ AA for $6 \mathrm{~min}$, the suspension containing $E$. carotovora subsp. carotovora, E. carotovora subsp. atroseptica, or E. chrysanthemi was plated on nonselective BHIA and on selective CVP and VRBA to compare the killing and injury effect of AA on five different species or trains of Erwinia. To determine the effect of acid concentration and exposure time on killing and injury, E. carotovora subsp. carotovora strain SR319 cells were treated with different concentrations (0.06 to $0.60 \%$ ) of AA for 6 min or with $0.3 \%$ AA for 2 to 10 min and subsequently plated on BHIA and VRBA.

Repair of bacterial injury in nutrient broth containing or lacking selective agents. Nutrient broth (NB; BD Systems/Difco) and NB supplemented with sodium dodecyl sulfate (SDS; $100 \mu \mathrm{g} / \mathrm{ml})$ and crystal violet $(1 \mu \mathrm{g} / \mathrm{ml})$ were inoculated with AAtreated E. carotovora subsp. carotovora (strain SR319) cells to make an initial cell concentration of approximately $3 \log \mathrm{CFU} / \mathrm{ml}$. Inoculated flasks were incubated at $20^{\circ} \mathrm{C}$ undisturbed for up to $8 \mathrm{~h}$. The samples were taken at $2-\mathrm{h}$ intervals to monitor the changes in the proportions of injured and recovered cells by plating the samples on BHIA and CVP. Injured cells were prepared by exposing E. carotovora subsp. carotovora cells from 24-h cultures to $0.3 \%$ AA for $6 \mathrm{~min}$. The steady decline in the number of injured cells during the incubation period was assumed to result from the resuscitation of injured cells.

Resuscitation of acid-injured Erwinia cells on apple and cucumber fruit. Unwaxed apple (Golden Delicious) and cucumber were purchased from the packer or local grocers, respectively. They were cleaned with laboratory detergent (Liquid-Nox; Alconox Inc., NY) and tap water and surface sanitized with 85\% ethanol (18). Injured E. carotovora subsp. carotovora strain SR319 cells were prepared by exposing the bacteria from 24-h cultures to $0.3 \%$ AA for $6 \mathrm{~min}$. A sterile nitrocellulose membrane $(0.45 \mu \mathrm{m}$; $25 \mathrm{~mm}$ in diameter; Millipore Inc., Bedford, MA) was placed on cut surface of apple or cucumber fruit and then inoculated with $50 \mu \mathrm{l}$ of AA-treated bacterial suspension containing approximately $10^{4} \mathrm{CFU}$ of injured cells. The inoculated membrane then was covered with apple or cucumber slices to ensure close contact between the membrane and fruit tissue. After incubation at $20^{\circ} \mathrm{C}$ for $0,4,8$, and $16 \mathrm{~h}$, two membranes at each sampling time were removed and each membrane was immersed in $5 \mathrm{ml}$ of PBS followed by vigorous shaking for $30 \mathrm{~s}$. Aliquots $(50 \mu \mathrm{l})$ of the suspension then were plated on BHIA and CVP to determine the changes in the populations of the injured and uninjured cells during the incubation.

TABLE 1. Recovery of Erwinia carotovora subsp. carotovora cells on selective and nonselective agar media following exposure to $0.3 \%$ acetic acid (AA) or to water (as control) for 6 min $^{\mathrm{w}}$

\begin{tabular}{|c|c|c|c|c|}
\hline \multirow[b]{2}{*}{$\operatorname{Media}^{x}$} & \multicolumn{2}{|c|}{ Water treated } & \multicolumn{2}{|c|}{ Acid treated } \\
\hline & Plate count $(\log \mathrm{CFU} / \mathrm{ml})$ & Plating efficiency ${ }^{y}$ & Plate count $(\log \mathrm{CFU} / \mathrm{ml})$ & Log CFU killed $(\mathrm{K})$ or injured $(\mathrm{I})^{\mathrm{z}}$ \\
\hline \multicolumn{5}{|c|}{ Nonselective } \\
\hline BHIA & $9.1 \pm 0.0 \mathrm{a}$ & $\ldots$ & $7.7 \pm 0.1 \mathrm{~b}$ & $1.4(\mathrm{~K})$ \\
\hline CVP & $9.1 \pm 0.2 \mathrm{a}$ & 92 & $3.8 \pm 0.1 \mathrm{c}$ & 3.9 (I) \\
\hline PT & $9.1 \pm 0.1 \mathrm{a}$ & 100 & $5.3 \pm 0.2 \mathrm{~d}$ & 2.4 (I) \\
\hline D3 & $9.0 \pm 0.3 \mathrm{a}$ & 77 & $3.9 \pm 0.3 \mathrm{cc}$ & 3.8 (I) \\
\hline
\end{tabular}

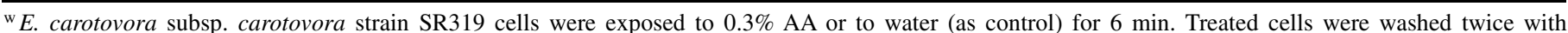
phosphate-buffered saline to remove residual AA and then plated on selective and nonselective agars. Inoculated agar plates were incubated at $28^{\circ} \mathrm{C}$ for $48 \mathrm{~h}$ prior to the counting. Values represent the average of three experiments with two duplicates in each experiment \pm standard deviation. Within a column, numbers not followed by the same letter are significantly different $(P<0.05)$ by the Bonferroni least significant difference separation technique $(22)$.

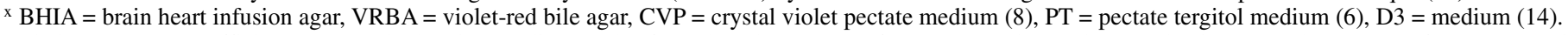

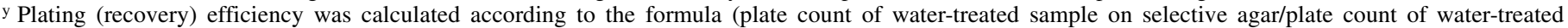
sample on BHIA) $\times 100$.

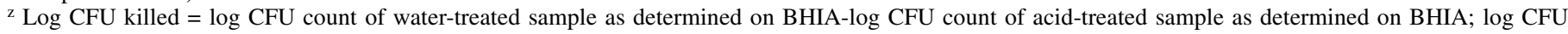
injured $=\log$ CFU count of acid-treated sample as determined on BHIA-log CFU count of acid-treated sample as determined on selective agar. 
Infectivity assays. Green bell pepper fruit purchased from local grocers were cleaned and surface sanitized with $85 \%$ ethanol as previously described (16). Injured E. carotovora subsp. carotovora cells were prepared by exposing the bacteria from 24-h cultures to $0.3 \%$ AA for $6 \mathrm{~min}$; bacteria treated with sterile distilled water were used as controls. The killing and injuring rates of AA treatment were determined as described above. Tenfold serial dilutions of AA- or water-treated samples were prepared and 5- $\mu$ l aliquots of each dilution were deposited on the wounded surface of green bell pepper (17). Wounding was made by puncturing the fruit with a $26-\mathrm{G}$ syringe 15 times to generate a site of approximately 2 to $3 \mathrm{~mm}$ in diameter. In each experiment, water- or AA-treated samples from each dilution were inoculated at three different sites on one fruit and the experiment was repeated three times. Inoculated bell pepper fruit were placed in a moist chamber and kept at $20^{\circ} \mathrm{C}$ for 2 days. Development of soft rot was recorded and percent of infectivity was calculated based on the formula number of sites developing soft rot/number of sites inoculated $(n=9) \times 100$.
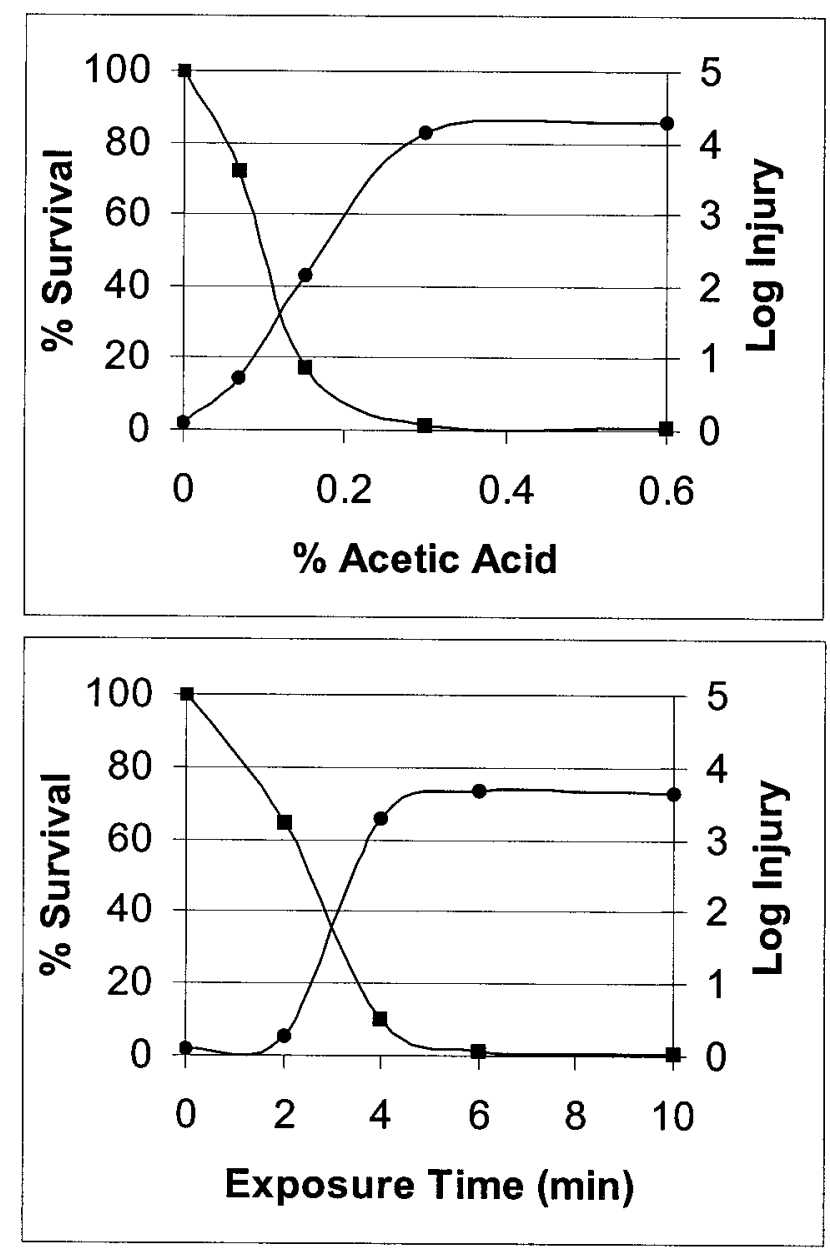

Fig. 1. Bactericidal and injury effects of acetic acid (AA) on Erwinia carotovora subsp. carotovora SR319 as affected by acid concentration (top) and exposure time (bottom). E. carotovora subsp. carotovora cells from a 18-h culture were treated with various concentrations $(0.0$ to $0.6 \%)$ of AA for $6 \mathrm{~min}$ or treated with $0.3 \%$ AA for different periods of time (2 to $10 \mathrm{~min}$ ). After removal of AA, treated samples were plated on brain heart infusion agar (BHIA) and violet-red bile agar (VRBA) to determine the killing and injury effect of AA on E. carotovora subsp. carotovora . Percent survival = (CFU count of the sample treated with AA as determined on BHIA/CFU count of sample treated with water - CFU count of the sample treated with AA) $\times 100$. Log injury $=\log$ CFU count of AA-treated sample as determined on BHIA - $\log$ CFU count of the same sample as determined on VRBA. The percent survival (@) and log injury (@) rates were determined as described in the text.
Statistical analysis. Resuscitation responses in broth or on cut surfaces of fruit were analyzed by performing analysis of variance to determine the effect of incubation time or environments. Differences between incubation times or environments were performed using the Bonferroni least significant difference mean separation procedure at the $P=0.05$ significance level (22).

\section{RESULTS}

Detection and enumeration of acid-injured cells. Bacterial counts in the samples treated with AA as determined on BHIA were $\approx 96 \%$ or $1.4 \log$ units lower than those treated with water (Table 1). In addition, colony sizes of AA-treated cells were smaller, in general, than those formed by water-treated cells after incubation at $28^{\circ} \mathrm{C}$ for $48 \mathrm{~h}$. The reduction in plate count on BHIA was assumed to be caused by the bactericidal action of AA and the reduction in colony size was due to the extended lag phase required for recovery of injured cells. When AA-treated samples were plated on both selective and nonselective agar media, the number of E. carotovora subsp. carotovora cells recovered on selective agars, including CVP, PT, D3, and VRBA, was 2.4 to $4.3 \log$ units (>99\%) lower than those recovered on BHIA (Table 1 ), indicating that injured cells failed to recover and form colonies on selective media. A significantly $(P<0.05)$ higher injury rate was obtained when the sample was plated on VRBA, D3, or CVP than on PT (Table 1). Bacterial counts of water-treated samples as determined on VRBA or D3 were lower, in general (23 to 26\%), than those determined on PT or CVP medium, indicating that higher selectivity or lower recovery efficiency as observed with VRBA and D3 media also impeded or delayed the recovery of injured cells.

Antimicrobial action of AA on Erwinia spp. as affected by acid concentration and exposure time. A positive correlation was observed between the killing or injury rate and the concentration of AA tested (Fig. 1). Upon exposure to $0.6 \%$ AA for $6 \mathrm{~min}, 99.5 \%$ (or more than 2 log units) of E. carotovora subsp. carotovora cells were killed. The number of viable $E$. carotovora subsp. carotovora cells as determined on BHIA was reduced from $1.5 \times 10^{9}$ to $8.0 \times 10^{6} \mathrm{CFU} / \mathrm{ml}$ following acid treatments. Among surviving E. carotovora subsp. carotovora cells, only a small fraction $\left(4.2 \times 10^{2} \mathrm{CFU} / \mathrm{ml}\right)$ was able to form colonies on VRBA, indicating that $99.99 \%$ (or more than $4 \log$ units) of surviving cells were injured. A positive correlation was observed between the exposure time and killing or injuring effects (Fig. 1). The longer the exposure time, the higher death rates were observed. For examples, following exposure to $0.3 \%$ AA for $10 \mathrm{~min}$, the number of surviving E. carotovora subsp. carotovora cells as determined on BHIA decreased from $1.7 \times 10^{9}$ to $8.0 \times 10^{6} \mathrm{CFU} / \mathrm{ml}$, but the number of surviving cells as determined on VRBA decreased very sharply from $1.4 \times 10^{9}$ to $1.8 \times 10^{3} \mathrm{CFU} / \mathrm{ml}$. Similarly, following exposure to $0.3 \%$ AA for 6 min, more than $90 \%$ of cells were killed and more than $99.9 \%$ (or $3 \log$ units) of the surviving cells were injured.

Variation in responses of Erwinia spp. or strains to AA antimicrobial action. Five representative strains of soft-rotting Erwinia spp., including two strains each of E. carotovora subsp. carotovora and E. chrysanthemi and one strain of E. carotovora subsp. atroseptica, were treated with $0.3 \%$ AA for $6 \mathrm{~min}$ and subsequently plated on nonselective BHIA and selective CVP and VRBA media to compare the relative susceptibility of bacterial strains to AA actions. The responses of soft-rotting Erwinia spp. to AA treatments varied among the strains or species examined (Fig. 2). Two E. chrysanthemi strains were significantly $(P<0.05)$ more susceptible to injuring action of AA than E. carotovora subsp. carotovora and E. carotovora subsp. atroseptica strains. For example, exposure of E. carotovora subsp. carotovora (strains SR319 and 1) to $0.3 \%$ AA for 6 min resulted in the reduction in plate count on BHIA by 1.4 and $1.9 \log$ units, respectively. By 
comparison, exposure of E. chrysanthemi strains to AA under the same condition resulted in the reduction in plate count by more than $2 \log$ units. Regardless of the strain tested, $>99.9 \%$ (or $3 \log$ units) of surviving cells were injured as indicated by their inability to form colonies on CVP or VRBA.

Resuscitation of acid-injured $\boldsymbol{E}$. carotovora subsp. carotovora cells in nutrient broth. When nonselective NB was inoculated with AA-treated E. carotovora subsp. carotovora cell suspension and incubated at $20^{\circ} \mathrm{C}$ for up to $8 \mathrm{~h}$, a steady increase in colony count on CVP and a steady decrease in the difference of bacterial counts as determined on CVP and on BHIA were observed (Fig. 3). Some recovery already is evident after $2 \mathrm{~h}$ of incubation in NB and the recovery continued to increase for up to $8 \mathrm{~h}$ (Fig. 3). Total bacterial count on BHIA decreased slightly during the first $8 \mathrm{~h}$ of incubation from 6.5 to $6.2 \mathrm{log}$ units, a steady increase in bacterial counts on CVP resulted more likely from the recovery of injured cells, but not from the multiplication of uninjured cells. Furthermore, the population of untreated cells increased by less than $0.4 \log$ units after incubation in NB for $8 \mathrm{~h}$ (data not shown). However, when injured E. carotovora subsp. carotovora cells were placed in NB containing crystal violet and SDS, a sharp decline in bacterial count $(2.2 \log \mathrm{CFU} / \mathrm{ml})$ was observed on BHIA during the first $2 \mathrm{~h}$ of incubation. Plate counts as determined on CVP showed little change throughout the 8-h incubation period. This result indicated that injured cells failed to resuscitate in NB containing crystal violet and SDS and were more vulnerable to bactericidal activities of selective agents present in selective media.

Resuscitation of acid-injured $\boldsymbol{E}$. carotovora subsp. carotovora cells on cut surfaces of cucumber fruit. To compare the resuscitation of injured cells on cut surfaces of cucumber and apple fruit, bacterial counts on selective (VRBA) and nonselective (BHIA) media were determined for injured cells that had been incubated on cucumber or apple for 4,8 , and $16 \mathrm{~h}$. Although little change in bacterial counts as determined on BHIA was found with samples that had been incubated on cucumber for up to $8 \mathrm{~h}$, bacterial counts on VRBA continued to increase during the same period (Table 2). This result indicated that the proportion of injured cells in the samples declined from 96 to $59 \%$ during the first $8 \mathrm{~h}$ of incubation. A marked increase in the population of $E$. carotovora subsp. carotovora (1.7 log units) and a marked decrease in the population of injured cells were observed with samples which had been incubated on cucumber for $16 \mathrm{~h}$. However, the number of bacteria recovered on VRBA was still $20 \%$ fewer than those recovered on BHIA, possibly due to the lower plating efficiency of VRBA as revealed in Table 1 . When filter membranes containing injured E. carotovora subsp. carotovora cells were incubated on cut surfaces of apple fruit, total bacterial counts

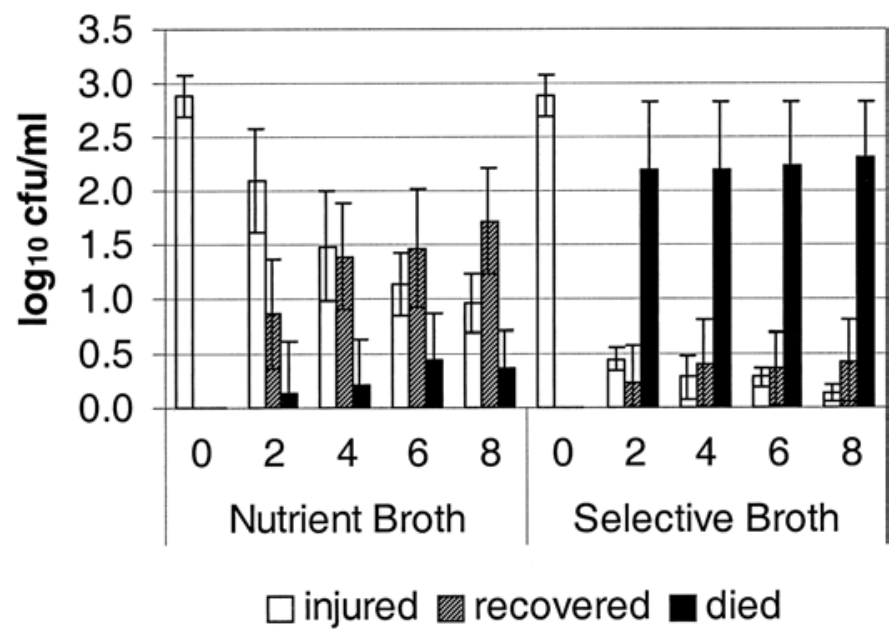

Fig. 3. Comparison of the recovery of acid-injured Erwinia carotovora subsp. carotovora cells in nutrient broth and in selective broth containing crystal violet $(1 \mu \mathrm{g} / \mathrm{ml})$ and sodium dodecyl sulfate $(100 \mu \mathrm{g} / \mathrm{ml})$. Both selective and nonselective nutrient broths containing injured cells at an initial concentration of $2.9 \log \mathrm{CFU} / \mathrm{ml}$ were incubated at $20^{\circ} \mathrm{C}$ for up to $8 \mathrm{~h}$. Samples were collected at 2-h intervals and plated on brain heart infusion agar and crystal violet pectate to monitor the number of injured and recovered cells during the incubation. Number of dead cells $=$ total number of cells at $\mathrm{T}_{0}(2.9 \mathrm{CFU} / \mathrm{ml}$ - number of cells injured - number of cells recovered.

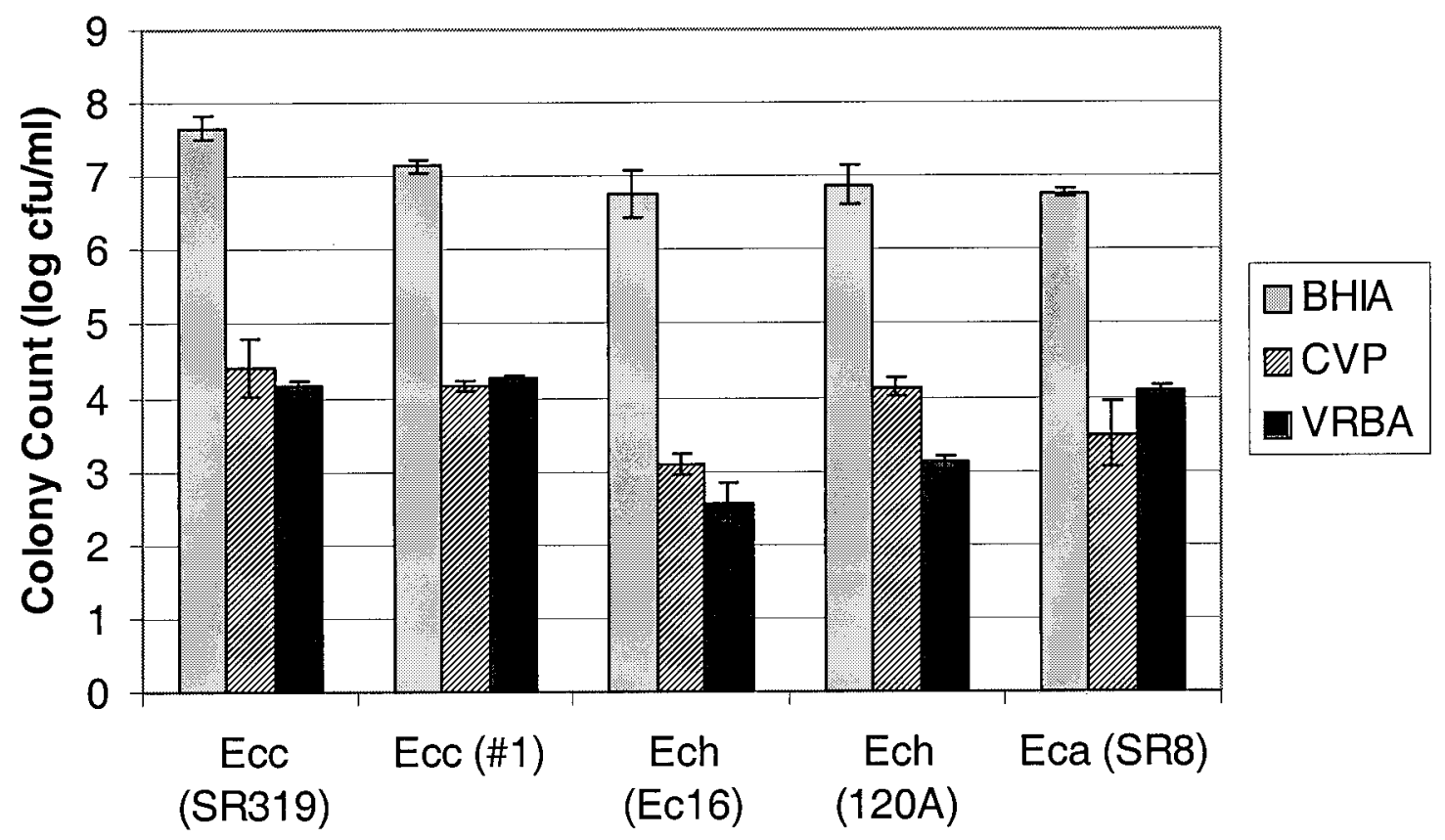

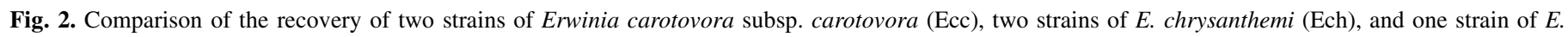

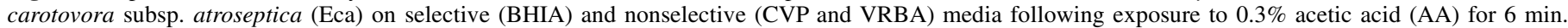

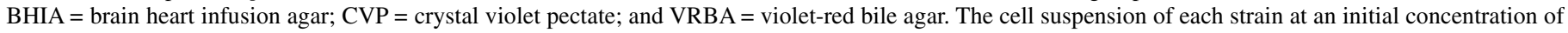

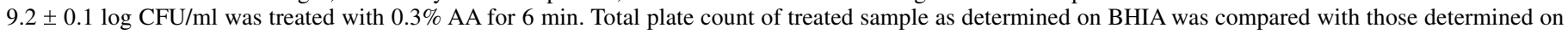
CVP or VRBA. 
on both BHIA and VRBA showed slight decline during the incubation and the percentage of injured cells in the population showed little change (Table 2). No sign of recovery was observed when injured cells were placed on apple fruit. Injured E. carotovora subsp. carotovora cells were able to repair the injury only on cut surfaces of cucumber fruits but not cut surfaces of apple fruit.

Soft-rotting ability of acid-injured $E$. carotovora subsp. carotovora cells. Green bell pepper fruit were inoculated with AA- or water-treated E. carotovora subsp. carotovora cell suspensions at the concentrations ranging from $10^{9}$ to $10^{3} \mathrm{CFU} / \mathrm{ml}$. The minimal concentration of water-treated (or uninjured) and AAtreated cells required for induction of soft rot was estimated to be $3.8 \times 10^{5}$ and $3.2 \times 10^{6} \mathrm{CFU} / \mathrm{ml}$, respectively. Only $5 \mu \mathrm{l}$ of bacterial suspension was deposited on the inoculation site; therefore, the total number of uninjured E. carotovora subsp. carotovora cells (from water-treated samples) required for induction of soft rot on bell pepper fruit was estimated to be $1.9 \times 10^{3} \mathrm{CFU}$. By comparison, the minimal number of acid-treated cells required for induction of soft rot on bell pepper fruit was estimated to be $1.6 \times$ $10^{4}$ CFU. Because $>99.9 \%$ of viable E. carotovora subsp. carotovora cells in AA-treated sample were injured, it was estimated that only one uninjured cell was present in $5 \mu \mathrm{l}$ of inoculum. Therefore, induction of soft rot by AA-treated samples was not due to the presence of uninjured cells but due to the resuscitation of injured cells.

\section{DISCUSSION}

Data presented here show that exposing Erwinia cells to low concentrations of AA can cause death and injury in all of five Erwinia strains examined. Injured cells could be detected and enumerated based on their differential abilities to form colonies on nonselective medium such as BHIA but not on selective agar media such as CVP, D3, PT, and VRBA. Those cells capable of forming colonies on BHIA but not on selective agars were considered "injured" as previously defined $(7,27)$. Injury rate determination was dependent on the type of selective medium used and also on the physiological stage of bacteria tested (4). We found that, after exposure to $0.3 \%$ AA for $6 \mathrm{~min}$, the number of E. carotovora subsp. carotovora cells recovered on BHIA was $10^{2}$ - to $10^{4}$-fold higher than those recovered on selective agars (Table 1). Poor recovery of injured Erwinia cells on selective media indicates that direct plating of samples on CVP is not suitable for recovering injured Erwinia cells possibly present in the samples that have been treated with heat, irradiation, or chemicals. The limitation of using selective media for detection of specific bacteria in processed foods has long been recognized (1). However, detection of injured Erwinia spp. in the environment or sanitized produce samples has not yet been reported. Based on our knowledge about injury in Escherichia coli K-12 (26) and S. typhimurium (11), it is not unreasonable to predict the presence of injured Erwinia cells in soil, irrigation water, or dehydrated plant debris. However, bacteria that are injured could be differentiated from those defined as viable but nonculturable (VNC) dormant cells (23). The VNC cells are considered nonculturable by the normal microbiological methods, whereas injured cells are considered culturable if they are placed on nonselective agar media containing no inhibitory substances or conditions.

In this study, we demonstrated that injured Erwinia cells would resuscitate in nonselective nutrient broth but not in broth containing SDS or crystal violet. Pre-enrichment of the samples in nonselective broth before plating them on selective agar such as CVP should aid the recovery of injured bacteria and improve the detection of Erwinia spp. This enrichment step is a standard practice for isolation of foodborne pathogens from clinical or food samples (1). Although such enrichment steps may not be necessary for isolation of Erwinia spp. from newly infected plant tissue, it should be considered when isolating Erwinia spp. from samples that have been exposed to physical or chemical stresses. An enrichment technique for improving the isolation of Erwinia spp. from soil has been described (21) and later applied to study the ecology of pathogens in potato fields (25). Semiselective broth, as described in these reports, was used mainly to increase the proliferation of pectolytic bacteria and to suppress the growth of aerobic native bacteria. It has not been determined if incubation of soil in this semiselective broth improves the recovery of injured Erwinia cells. It also is not known if soil extracts added to this nutritionally limited broth (21) may impede the repair of injured cells. Inability of the heat-injured Salmonella sp. or Escherichia coli cells to resuscitate on minimal medium has been demonstrated previously (27). Enrichment of root or soil samples in PT broth (6) before plating on indicator media also has been shown to improve the recovery of Erwinia spp. $(9,20)$. The surfactant Tergitol in PT broth is toxic and expected to inhibit the resuscitation of injured Salmonella cells (1) and possibly Erwinia cells, as shown in this study. Therefore, the advantage of incubating the samples in PT broth possibly is not due to the enhancement of recovery of injured cells, but to the suppression of untargeted bacteria.

Although the clinical importance of injured gastrointestinal pathogens in humans cannot be easily determined, Sorrells et al. (30) reported that freezing-injured $S$. gallinarum cells showed no loss of virulence in chickens. In this study, we also found that acid-injured Erwinia cells were able to resuscitate and to induce soft rot on bell pepper fruit. An $\approx 10$-fold higher number of injured cells $\left(3.2 \times 10^{6} \mathrm{CFU} / \mathrm{ml}\right)$ than the uninjured counterpart $(3.8 \times$ $\left.10^{5} \mathrm{CFU} / \mathrm{ml}\right)$ is required to induce soft rot. The requirement of a higher number of injured cells to induce soft rot possibly is due to the fact that severely injured cells might eventually die or fail to revive on fruit (Fig. 3). The ability of injured Erwinia cells to repair probably is dependent on the type of fruit and environmental conditions tested. We have observed (data not shown) that acid-injured Erwinia cells are unable to recover in PBS, in apple juice $(\mathrm{pH} 3.41)$, or at refrigeration temperature $\left(4^{\circ} \mathrm{C}\right)$. Washing fresh produce with organic acids such as AA or storage at low temperatures may be effective in controlling soft rot caused by uninjured and injured Erwinia spp.

TABLE 2. Resuscitation of acid-injured Erwinia carotovora subsp. carotovora cells on cut surfaces of cucumber and apple fruit ${ }^{\mathrm{y}}$

\begin{tabular}{|c|c|c|c|c|c|c|}
\hline \multirow[b]{2}{*}{ Incubation time $(\mathrm{h})$} & \multicolumn{3}{|c|}{ Cucumber, plate count (log CFU/membrane) on } & \multicolumn{3}{|c|}{ Apple, plate count (log CFU/membrane) on } \\
\hline & BHIA & VRBA & Injury $(\%)^{\mathrm{z}}$ & BHIA & VRBA & Injury $(\%)^{\mathrm{z}}$ \\
\hline 0 & $5.3 \pm 0.2 \mathrm{a}$ & $3.9 \pm 0.1 \mathrm{a}$ & $96 \mathrm{a}$ & $4.9 \pm 0.3 \mathrm{a}$ & $3.8 \pm 0.4 \mathrm{a}$ & $93 \mathrm{a}$ \\
\hline 4 & $5.3 \pm 0.1 \mathrm{a}$ & $4.2 \pm 0.2 b$ & $91 \mathrm{~b}$ & $4.7 \pm 0.1 \mathrm{a}$ & $3.7 \pm 0.2 \mathrm{a}$ & $94 \mathrm{a}$ \\
\hline 8 & $5.3 \pm 0.3 \mathrm{a}$ & $4.9 \pm 0.3 c$ & $59 c$ & $4.3 \pm 0.2 b$ & $3.0 \pm 0.3 b$ & $95 \mathrm{a}$ \\
\hline 16 & $7.0 \pm 0.4 \mathrm{~b}$ & $6.5 \pm 0.2 \mathrm{~d}$ & $20 \mathrm{~d}$ & $4.5 \pm 0.1 b$ & $2.9 \pm 0.4 b$ & $97 \mathrm{a}$ \\
\hline
\end{tabular}

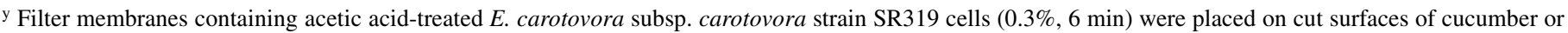

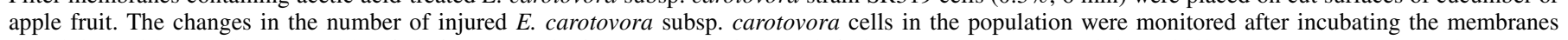
containing acid-treated cells on either fruit for 4, 8, and $16 \mathrm{~h}$. BHIA = brain heart infusion agar and VRBA = violet-red bile agar. Values represent the average of three experiments with two duplicates in each experiment \pm standard deviation. Within a column, the numbers not followed by the same letter are significantly different $(P<0.05)$ by the Bonferroni least significant difference separation technique $(22)$.

${ }^{\mathrm{z}}$ Percent injury $=([$ plate count on BHIA - plate count on VRBA]/plate count on BHIA $) \times 100 \%$. 
Because of its bactericidal activity, AA has been used for food preservation and for decontamination of animal carcasses (11). A number of studies already have shown that exposure to low concentrations of AA can suppress postharvest rot of fruit (29) and eliminate gastrointestinal pathogens from apple $(32,33)$, parsley (15), and mung bean seed (10). Results from a separate study (data not shown) showed that a mixture of AA and $\mathrm{H}_{2} \mathrm{O}_{2}$ is more effective than other common sanitizers in removing Salmonella cells attached to cut surfaces of apple slices. By considering the minimal concentration of $\mathrm{AA}$ and exposure time required to achieve the same level of death or injury rate, Erwinia spp. are much more susceptible to AA action than S. bareilly (5) and Escherichia coli K-12 (26). Although AA is less toxic than other sanitizers, it is able to cause sublethal injury in an extremely large proportion of cells even at relatively low concentrations $(<0.1 \%)$. Thus, washing fresh produce with AA, possibly in combination with other sanitizers, provides effective means for inactivating harmful bacteria on surfaces of plants.

\section{ACKNOWLEDGMENTS}

Mention of brand or trade name does not constitute an endorsement by the U.S. Department of Agriculture over others of a similar nature not mentioned. We thank G. Hoffman for technical assistance and J. Smith, B. Fett, and V. Juneja for critical review and discussion during the preparation of this manuscript.

\section{LITERATURE CITED}

1. Andrew, W. H. 1990. Methods for recovering injured "classical" enteric pathogenic bacteria (Salmonella, Shigella and enteropathogenic Escherichia coli) from foods. Pages 55-113. in: Injured Index and Pathogenic Bacteria: Occurrence and Detection in Foods, Water and Feeds. B. Ray, ed. CRC Press, Inc. Boca Raton, FL.

2. Bartz, J. A. 1999. Washing fresh fruits and vegetables: Lessons from treatment of tomatoes and potatoes with water. Dairy Food Environ. Sanit. 19:853-864.

3. Beuchat, L. R. 1998. Surface decontamination of fruits and vegetables eaten raw: A review. Food Safety Unit, WHO/FSF/FPS/98.2.

4. Beuchat, L. R., and Lechowich, R. V. 1968. Survival of heated Streptococcus faecalis as affected by phase of growth and incubation temperature after thermal exposure. J. Appl. Bacteriol. 31:414419.

5. Blankenship, L. C. 1981. Some characteristics of acid injury and recovery of Salmonella bareilly in a model system. J. Food Prot. 44: 73-77.

6. Burr, T. J., and Schroth, M. N. 1977. Occurrence of soft-rot Erwinia spp. in soil and plant material. Phytopathology 67:1382-1387.

7. Busta, F. F. 1976. Practical implications of injured microorganisms in foods. J. Milk Food Technol. 39:138-145.

8. Cuppels, D., and Kelman, A. 1974. Evaluation of selective media for isolation of soft-rot bacteria from soil and plant tissue. Phytopathology 64:468-475.

9. De Boer, S. H., Allan E., and Kelman, A. 1979. Survival of Erwinia carotovora in Wisconsin soils. Am. Potato J. 56:243-252.

10. Delaquis, P. J., Sholberg, P. L., and Stanich, K. 1999. Disinfection of mung bean seed with gaseous acetic acid. J. Food Prot. 62:953-957.

11. Dickson, J. S. 1992. Acetic acid action on beef tissue surfaces contaminated with Salmonella typhimurium. J. Food Sci. 57:297-301.
12. Food and Drug Administration (FDA). 1982. GRAS status of acetic acid, ammonium acetate, sodium acetate, and sodium diacetate. Fed. Regis. 47:27813.

13. Hartseli, S. E. 1951. The longevity and behavior of pathogenic bacteria in frozen food, the influence of plating media. Am. J. Public Health 41:1072-1075.

14. Kado, C. I., and Heskett, M. G. 1970. Selective media for isolation of Agrobacterium, Corynebacterium, Erwinia, Pseudomonas, and Xanthomonas. Phytopathology 60:969-976.

15. Karapinar, M., and Gönül, S. A. 1992. Removal of Yersinia enterocolitica from fresh parsley by washing with acetic acid or vinegar. Int. J. Food Microbiol. 16:261-264.

16. Liao, C.-H., and Cooke, P. H. 2001. Response to trisodium phosphate treatment of Salmonella Chester attached to fresh-cut green pepper slices. Can. J. Microbiol. 47:25-32.

17. Liao, C.-H., Hung, H.-Y., and Chatterjee, A. K. 1988. An extracellular pectate lyase is the pathogenicity factor of the soft-rotting bacterium Pseudomonas viridiflava. Mol. Plant-Microbe Interact. 1:199-206.

18. Liao, C.-H., and Sapers, G. M. 2000. Attachment and growth of Salmonella Chester on apple fruits and in vivo response of attached bacteria to sanitizer treatments. J. Food Prot. 63:876-883.

19. Lund, B. M. 1983. Bacterial spoilage. Pages 219-257 in: Postharvest Pathology of Fruits and Vegetables. C. Dennis, ed. Academic Press, Inc., New York.

20. McCarter-Zorner, N. J., Harrison, M. D., Franc, G. D., Quinn, C. E., Ann Sells, I., and Graham, D. C. 1985. Soft-rot Erwinia bacteria in the rhizosphere of weeds and crop plants in Colorado, United States and Scotland. J. Appl. Bacteriol. 59:357-368.

21. Meneley, J. C., and Stanghellini, M. E. 1976. Isolation of soft-rot Erwinia spp. from agricultural soils using an enrichment technique. Phytopathology 66:367-370

22. Miller, R. G. 1981. Simultaneous Statistical Inference, 2nd ed. SpringerVerlag, New York.

23. Montville, T. J. 1997. Principals which influence microbial growth, survival, and death in foods. Pages 13-29. in: Food MicrobiologyFundamentals and Frontiers. M. P. Doyle, L. R. Beuchat, and T. J. Montville, eds. ASM Press, Washington, DC

24. Pérombelon, M. C. M., and Kelman, A. 1980. Ecology of the soft rot erwinias. Annu. Rev. Phytopathol. 18:361-387.

25. Powelson, M. L., and Apple, J. D. 1984. Soil and seed tubers as sources of inoculum of Erwinia carotovora subsp. carotovora for stem soft rot of potatoes. Phytopathology 74:429-432.

26. Przybylski, K. S., and Witter, L. D. 1979. Injury and recovery of Escherichia coli after sublethal acidification. Appl. Environ. Microbiol. 37:261-265.

27. Ray, B. 1979. Methods to detect stressed microorganisms. J. Food Prot. 42:346-355.

28. Sapers, G. M., and Simmons, G. F. 1998. Hydrogen peroxide disinfection of minimally processed fruits and vegetables. Food Technol. 52:48-52.

29. Sholberg, P., Haag, P., Hocking, R., and Bedford, K. 2000. The use of vinegar vapor to reduce postharvest decay of harvested fruit. HortScience 30:1271-1275.

30. Sorrells, K. M., Speck, M. L., and Warren, J. A. 1970. Pathogenicity of Salmonella gallinarum after metabolic injury by freezing. Appl. Microbiol. 19:39-43.

31. Tsai, L. S., Huxsoll, C. C., and Robertson, G. 2001. Prevention of potato spoilage during storage by chlorine dioxide. J. Food Sci. 66:472-477.

32. Wisniewsky, M. A., Glatz, B. A., Gleason, M. L., and Reitmeier, C. A. 2000. Reduction of Escherichia coli O157:H7 counts on whole fresh apples by treatment with sanitizers. J. Food Prot. 63:703-708.

33. Wright, J. R., Sumner, S. S., Hackney, C. R., Pierson, M. D., and Zoecklein, B. W. 2000. Reduction of Escherichia coli $\mathrm{O} 157: \mathrm{H} 7$ on apples using wash and chemical sanitizer treatments. Dairy Food Environ. Sanit. 20:120-126. 